\title{
The female therapist and the client's gender
}

\author{
Katja Kuusisto ${ }^{1,2}$, Tytti Artkoski \\ 1. Institute for Advanced Social Research, IASR, University of Tampere, Finland. 2. School of Social Sciences and \\ Humanities, University of Tampere, Finland.
}

Correspondence: Katja Kuusisto. Address: School of Social Sciences and Humanities, University of Tampere, FI-33014 University of Tampere, Finland. Email: katja.n.kuusisto@uta.fi

Received: February 4, 2013

Accepted: May 16, 2013

Online Published: May 31, 2013

DOI : $10.5430 /$ cns.v1n3p39

URL: http://dx.doi.org/10.5430/cns.v1n3p39

\section{Abstract}

Most Finnish substance abuse therapists are women, while the majority of clients are men. This study explores the gender-based differences in the therapeutic alliance, retention in therapy and outcomes between female therapists $(N=30)$ and their clients $(N=296$, women 101, men 195) in outpatient treatment. Female clients were more likely to want a female therapist, whereas men did not express such preferences. The clients' estimation of the therapeutic alliance differed at the first visit: female clients estimated it to be better than did men. The therapists' estimations were not connected to client's gender. The combination of a female therapist and a female client predicted a better therapeutic alliance during treatment, but there were no differences between male and female clients in long-term outcomes. The findings suggested that clients received treatment of the same quality regardless of their gender.

\section{Key words}

Substance abuse treatment, Outpatient, Therapist, Gender differences, Retention, Effectiveness, Therapeutic alliance

\section{I ntroduction}

Gender is one of the factors with bearing on the success of substance abuse treatment. Therapists in substance abuse treatment in Finland are predominantly female, while their clients are predominantly men. This is often the case in social work among different client groups ${ }^{[1]}$ and internationally in the caring professions in general. In spite of this, very little research has addressed the significance of both client's and therapist's gender in substance abuse treatment. Internationally the topic has received slightly more attention ${ }^{[2-4]}$ although gender has largely emerged in substance abuse research only since the $1990 \mathrm{~s}{ }^{[5]}$. However, research on gender has almost always been conducted in the Anglo-American countries. Might research on Nordic treatment practices yield different findings? Differences between the genders in terms of their treatment experience, consumption, related problems, social situation and life domain have been studied in the Nordic countries ${ }^{[6]}$. To the best of our knowledge studies on the effect of gender on treatment outcome have not been conducted in the more gender-equal Nordic countries. Indeed, this is an understudied area worldwide and the results so far have been inconsistent ${ }^{[7]}$. In this study we focus on whether female therapists are more successful in helping women or men as their clients in outpatient substance abuse treatment. In this context, we also try to ascertain the effect of matching gender (between therapist and client) on the treatment.

Problems with substance abuse continue to be perceived as a problem of men ${ }^{[8,9]}$, although recent decades have witnessed an increase in substance abuse among women ${ }^{[10]}$. In many respects Finland follows the same path as the other western 
countries. Due in part to the gender structure of the clientele, the implementation of gender-sensitive practices in substance abuse treatment has been relatively slow. Like Greenfield and Pirard ${ }^{[11]}$, we perceive gender-sensitivity to refer to practices in substance abuse treatment which have not been specifically designed for representatives of a given gender but which nevertheless take special features of the client's gender into consideration. The definition of the concept gender is based on the assumption that while the concept of sex focuses on biological differences between men and women, gender also includes the notion of male and female traits and behaviours that are culturally defined ${ }^{[7]}$. This is a multilayered context and as such it has to be taken into account, because in the treatment situation the client is encountered with diverse expectations over and above being a man or a woman in a biological sense. Therefore, in this article we use the term gender instead of sex.

In this study we understand social work and therapy work in Finnish substance abuse treatment system to be similar to each other. The literature reviewed here likewise comes from different directions; the original studies use both these terms depending on their focus group. Therefore, the terms social work and therapy work are used interchangeably. Similarly, occupational terms like social worker and therapist are used in the background section. Empirically, this study investigates therapists.

In social work the importance of gender-sensitivity, responding to the needs of both men and women, has been recognized internationally and research has described treatment practices taking gender into consideration ${ }^{[11]}$. In Finland gender-specific social work has not gained a similar footing ${ }^{[12,13]}$. There are indeed services in Finland intended specifically for women (i.e. groups and treatment units). There has also been an attempt to lower the threshold of entering treatment by providing services which support treatment seeking in various life situations and in spite of family responsibilities. There are more practices catering explicitly for clients' gender in institutional substance abuse treatment than in treatment in the community. In outpatient treatment clients of different genders are at a superficial level offered the same kinds of treatment, generally individual therapy. However, the content may (implicitly) be different with regard to gender.

Matching of therapy methods and clients' characteristics has produced almost no results ${ }^{[14-17]}$. Instead, matching focusing on objective characteristics like gender and ethnicity has produced more promising results ${ }^{[18]}$, but matching in this area, too, has produced somewhat mixed results ${ }^{[19]}$. These indicate that treatment methods are not fully able to respond to the special needs of different clients. It has been suggested that common factors are considerably more important for the outcome than the treatment methods in both psychotherapy and substance abuse treatment ${ }^{[20-24]}$. Taking into account the client's personal characteristics in treatment planning and provision is deemed relevant ${ }^{[25,26]}$.

The therapeutic alliance between client and therapist is deemed to be among the most significant factors with bearing on treatment outcome ${ }^{[27]}$. Therapist and client form a therapeutic dyad and both are considered responsible for its constitution and quality. Therefore, both participants' experiences are considered to contribute to the alliance ${ }^{[28]}$. Marcus, Kashy and Baldwin ${ }^{[29]}$ have further pointed out that this dyad is reciprocal. In other words, if the therapist evaluates the alliance as good, it is likely that client will do the same.

What then are the factors which determine the nature of the therapeutic alliance? The client's expectations with regard to treatment are one important factor ${ }^{[22]}$. In particular they shape women's treatment needs. It has been reported that the opportunity to exert influence over treatment content is more important to women than to men. For instance, women attached more importance to discussing the treatment programme and influencing their path through the treatment system. Taking this into account may increase women' satisfaction and promote their retention in treatment ${ }^{[24,30]}$.

According to psychotherapy research, some female clients prefer a woman therapist to a man therapist ${ }^{[31]}$. Some studies have reported that women attending female therapists commit better than women attending male therapists ${ }^{[32]}$, although opposite findings have been reported ${ }^{[11,33]}$. Gender matching of client and therapist is seen to be important to outcome specifically in individual therapy; client and therapist being of the same gender is more likely to lead to sobriety ${ }^{[34]}$. 
There have been indications that same-gender therapist-client dyads succeed better than those with different genders ${ }^{[35]}$. Research on the subject has shown that the needs of female clients differ from those of male clients; among others women's substance abuse problems and their progression, risk factors, treatment motivation and reasons for relapses differ from those of men ${ }^{[11,36]}$. In the gender differentiating view of treatment the needs of women and men are perceived to differ, thus good treatment can be considered to include (among other things) gender-sensitive services. Matching client and therapist for gender is considered to lay a creative foundation for cooperation based on a shared experience of gender and so on equality ${ }^{[12]}$.

More gender-sensitive treatment practices are seen as a response to various gender needs. For men the need for gender-sensitive treatment has been stressed to be especially great in the treatment process of domestic violence ${ }^{[37]}$. As most Finnish substance abuse therapists are women, in male clients gender sensitive treatment may be impeded by the small number of male workers available.

The significance of gender has been discussed in Finnish social work with particular reference to client's male gender. Marjo Kuronen ${ }^{[13]}$ raised the issue of the practices of the social work office in that men might be alienated by the characteristics typical of women. It has been proposed that female workers do not necessarily have the skills to identify male clients' needs, and that men therefore do not meet with sufficient understanding ${ }^{[38]}$. Moreover, a man as client has been considered to constitute a challenge for a female worker, when the relationship is tinged by the conventions pertaining to the power relations of gender ${ }^{[39]}$. It has, for example, been established that female workers in particular find it difficult to work with aggressive male clients ${ }^{[37]}$. To some extent men are also perceived as such clients who do not find it so easy to start to discuss their problems as do women ${ }^{[12,40]}$.

Interpersonal factors are closely related to commitment to treatment and changes in substance abuse behaviour ${ }^{\text {[41-43] }}$. Therapists have been found to confront and criticize male clients more than do female clients in substance abuse treatment. This is attributable to therapists' stereotypical attitudes to clients of different genders ${ }^{[44]}$. The way of implementing treatment has also been found to differ to some extent according to therapist's gender. Therapist related characteristics like empathy and ability to form a therapeutic alliance are thought to be important factors affecting therapeutic change ${ }^{[45]}$. Confrontational style has been speculated to be more typical in male therapists. The appropriateness of the style has moreover been questioned in relation to women clients ${ }^{[46,47]}$. It has also been found that the clients of male therapists drop out of institutional treatment significantly more often than those of female therapists ${ }^{[48]}$. Furthermore, in another study the results showed that confrontational therapist style leads to increased drinking among clients ${ }^{[42]}$. It may be that female therapists are more successful than their male counterparts in avoiding the confrontations which lead to dropping out. However, there are also indications in the literature that so-called difficult clients end up with male social workers ${ }^{\text {[49] }}$.

The therapist's capacity for empathy is among his or her most important characteristics from the perspective of treatment outcome ${ }^{[23,50]}$. It has been found that differences in empathy persist between workers of different genders. Women are more empathetic and in addition they are keener than men to avoid excessive directiveness towards the client, which is likely to affect the quality of co-operation and commitment to treatment ${ }^{[51]}$.

The study at hand is concerned with the research of gendered practices in substance abuse treatment. The purpose of this study was to learn about the differences by gender in the therapeutic alliance, retention in treatment and effectiveness. The focus of interest is specifically the female therapist and the therapeutic alliance with her clients of different genders, and their retention in and outcome of treatment; the small number of male therapists in outpatient substance abuse treatment rendered impossible a research setup comparing therapists by gender. This study sought answers to the following questions:

- To what extent are there differences in the estimations of the therapeutic alliance assessed by the female therapists by client's gender or do corresponding estimations by the clients differ by gender? 
- What differences can be identified in continuity of treatment between the female and male clients of female therapists?

- What differences can be identified in the treatment outcomes of female and male clients of female therapists?

- To what extent can gender-matching of female therapists and their clients predict treatment results?

\section{Materials and methods}

\subsection{Research setup and materials used in the study}

The research was implemented as a multi-site study with the participation of outpatient clinics $(N=7)$ in southern and western Finland. The preparatory work began in spring 2007, when the directors of these clinics were informed about the project and their willingness to participate was elicited. All the units approached agreed to participate and their personnel were introduced to the research. Ethical approval for this study was received from The Ethics Committee of A-Clinic Foundation.

Specific principles were adhered to in the design and implementation of this prospective follow-up study. We applied a naturalistic research approach, meaning that the research was conducted as part of each clinic's normal activity. Apart from the randomization of clients to therapists and the completion of questionnaires, it did not interfere with the progress of treatment. A further aim was to use a minimal number of burdensome tools. This was an attempt to minimize the effect of the research on treatment outcomes. Also, the clients were non-selected; each consenting client beginning a treatment period due to a substance abuse problem was accepted as a research subject and all therapists at the participating clinics agreed to participate. Outpatient substance abuse treatment was based on individual therapy, as the case often is in Finnish outpatient substance use treatment. Clients were assigned to therapists according to a randomization list drawn up in advance to standardize background information. Clients' retention in treatment and outcome were monitored six months after the commencement of treatment. Clients had an opportunity to withdraw at every phase of the study without any effect on treatment received.

The data used in these analyses are partial data and consist of female therapists and their clients ${ }^{[52]}$. The data as a whole has been described in other publications ${ }^{[33,54]}$. The clients $(N=296)$ attended for treatment from January to June 2008 , and 101 (34.1\%) were women and 195 (65.9\%) were men. The follow-up visit six months after treatment entry was the only specifically determined meeting in the procedure. The times for therapy sessions were determined by the client's needs and the practices of the unit in question.

Figure 1 presents the progress of the study, the research materials used and numbers of clients in the various phases. Client participation began with the first visit to the unit's reception. Having received a brochure describing the research a client gave his/her consent to being a research subject. The client was apprised of the research ethics. Before commencing actual therapy clients completed a questionnaire (1; see Figure 1), which included questions related to demographic factors, information on substance use and attitudes to treatment. The questionnaire combined questions found useful in other studies ${ }^{[55,56]}$ and some structural measurements (e.g. Alcohol Addiction Self-Efficacy Scale; Readiness to Change). Each client was then randomly assigned to a therapist.

At the beginning of the research the background information of the therapist and therapeutic orientation were also elicited (2; see Figure 1). Additionally, the therapist monitored the progress of the client's treatment (3; see Figure 1) and during monitoring gave a code on the continuity of the client's treatment; retention in treatment might receive three values, 1 ) treatment completed as agreed, 2) treatment ongoing or 3) treatment discontinued. 
Both the client and the therapist estimated the interaction situation after a therapy session double-blinded to each other's answers. Clients attending for therapy completed a form at the end of their first and third sessions in which they estimated the therapeutic alliance, also known as the working alliance, assessed in terms of the co-operation between the participants in a therapy session ${ }^{[27,57,58]}$. The therapists $(N=30)$ completed the same forms. These forms $4,5,6$ and 7 (see Figure 1) were identical.

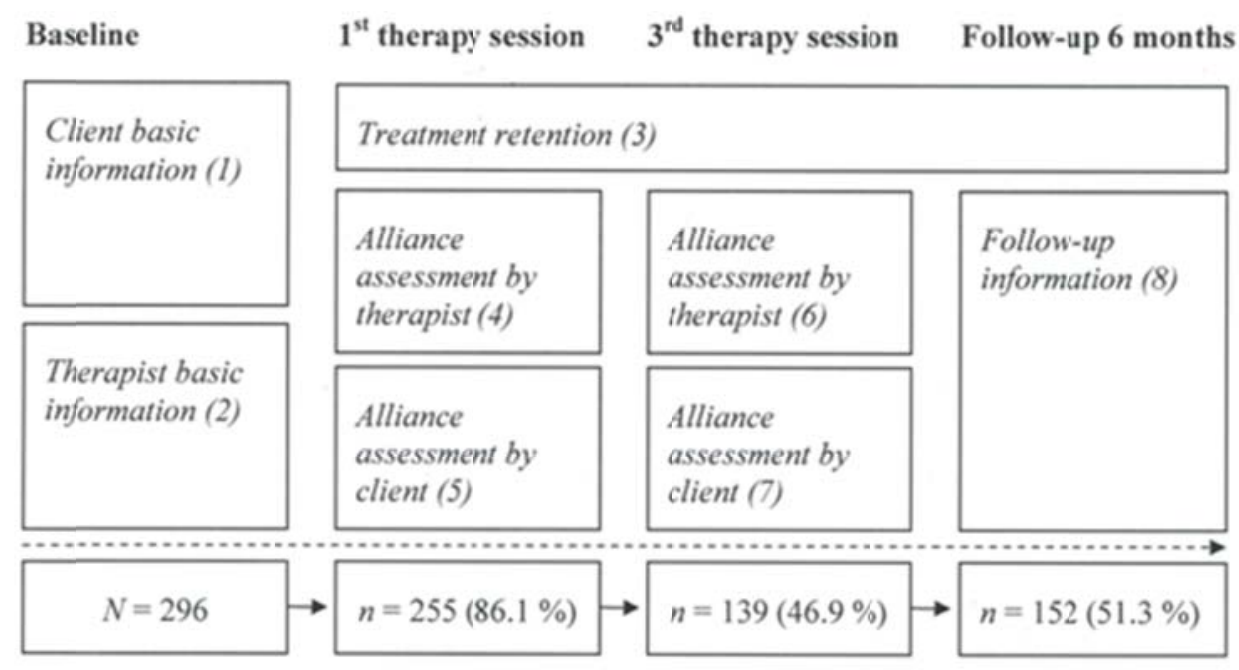

Figure 1. Research materials and number of clients at different stages in the research setup

Methodologically, there is a fair consensus in psychotherapy research on whose assessment of the working alliance is best in predicting treatment outcome. In some studies the therapist's perspective is emphasized ${ }^{[59]}$, in others the client's ${ }^{[60]}$, and in others that of both ${ }^{[61]}$ or that of an outsider ${ }^{[62]}$. In this study, we utilize both client and therapist assessments of the working alliance at two time-points during early treatment. This takes into account the face-to-face treatment situation and is based on an idea of dyadic nature in forming the alliance.

The instrument used in the measurement of the therapeutic alliance originated from Markku Ojanen ${ }^{[63]}$, who created it specifically as a tool for assessing a recent therapy session in psychotherapy research. When the research was being planned it was estimated not to be burdensome for treatment and easy to use as it only required one estimate on a scale from 0 (very poor connection) to 100 (very good reciprocal connection). The instrument has been found useful in the evaluation of interaction situations in substance abuse treatment ${ }^{[64]}$.

The research included a maximum of five sessions per client. A treatment period might continue thereafter but these subsequent sessions were no longer included in the research. The duration of the follow-up period can be justified by the dynamics of addiction, in that relapses most typically occur during that period ${ }^{[65]}$. All clients who completed the form for background information were invited to the unit by letter six months after the beginning of treatment for a follow-up visit. The treatment follow-up questionnaire (8; see Figure 1) elicited among other things substance abuse during the treatment period and satisfaction with help or support received from the therapist. This information was mostly used in the research as dependent variables.

\subsection{Participants}

Those participating in the research were clients beginning a new treatment period and their therapists. The clients had come to the treatment unit, which was determined on the basis of their places of residence. Inhabitants of both urban and sparsely populated areas were included. 
Table 1. Participants' $(N=296)$ background and substance abuse information by gender

\begin{tabular}{|c|c|c|c|}
\hline Variables & Woman $n(\%)$ & $\operatorname{Man} n(\%)$ & $p$ \\
\hline \multicolumn{4}{|l|}{ Age } \\
\hline-30 & $15(14.9)$ & $40(20.5)$ & \\
\hline $31-40$ & $17(16.8)$ & $47(24.1)$ & \\
\hline $41-50$ & $38(37.6)$ & $52(26.7)$ & \\
\hline $51-$ & $31(30.7)$ & $56(28.7)$ & \\
\hline Marital status & & & $*$ \\
\hline Single & $73(72.3)$ & $121(62.1)$ & \\
\hline Pair relationship & $28(27.7)$ & 74 (37.9) & \\
\hline Experienced sexual violence or exploitation $(n=292)$ & & & $\S$ \\
\hline Yes & $39(39.4)$ & $6(3.1)$ & \\
\hline No & $60(60.6)$ & $187(96.9)$ & \\
\hline \multicolumn{4}{|l|}{ Substances abused $(n=293)^{\dagger}$} \\
\hline Alcohol & $96(96.0)$ & $189(97.9)$ & \\
\hline Tranquilizers & $21(21.0)$ & $32(16.6)$ & \\
\hline Cannabis & $10(10.0)$ & $30(15.5)$ & \\
\hline Amphetamine & $8(8.0)$ & $24(12.4)$ & \\
\hline Buprenorphine & $4(4.0)$ & $13(6.7)$ & \\
\hline Opiates & $2(2.0)$ & $6(3.1)$ & \\
\hline Cocaine & $4(4.0)$ & $4(2.1)$ & \\
\hline LSD & $2(2.0)$ & $3(1.6)$ & \\
\hline Other (incl. substitutes, solvents) & $4(4.0)$ & $7(3.6)$ & \\
\hline \multicolumn{4}{|l|}{ Type of substance abuse $(n=292)^{\dagger}$} \\
\hline Single substance use & $78(78.0)$ & $138(71.9)$ & \\
\hline Poly-substance use & $22(22.0)$ & $54(28.1)$ & \\
\hline \multicolumn{4}{|l|}{ Habit of consuming substance $(n=287)^{\dagger}$} \\
\hline Daily or almost daily & $38(38.8)$ & $76(40.2)$ & \\
\hline Periodically & $36(36.7)$ & $79(41.8)$ & \\
\hline At weekends & $24(24.5)$ & $34(18.0)$ & \\
\hline \multicolumn{4}{|l|}{ Contacts with other abusers $^{\dagger}$} \\
\hline Daily or almost daily & $13(12.9)$ & $31(15.9)$ & \\
\hline Weekly & $21(20.8)$ & $53(27.2)$ & \\
\hline Monthly & $12(11.9)$ & $35(17.9)$ & \\
\hline Less frequently & $16(15.8)$ & $27(13.8)$ & \\
\hline No contacts & $39(38.6)$ & $49(25.1)$ & \\
\hline \multicolumn{4}{|l|}{ Attitudes towards AA/NA } \\
\hline Positive & $61(60.4)$ & $103(52.8)$ & \\
\hline Neutral & $34(33.7)$ & $71(36.4)$ & \\
\hline Negative & $6(5.9)$ & $21(10.8)$ & \\
\hline Prior admission to this clinic $(n=294)$ & & & $*$ \\
\hline Yes & $36(35.6)$ & $96(49.7)$ & \\
\hline No & $65(64.4)$ & $97(50.3)$ & \\
\hline \multicolumn{4}{|l|}{ Voluntary admission to this clinic $(n=295)$} \\
\hline Yes & $71(70.3)$ & $147(75.8)$ & \\
\hline No & $30(29.7)$ & $47(24.2)$ & \\
\hline \multicolumn{4}{|l|}{ Client's objective $(n=291)$} \\
\hline Abstinence & $42(42.0)$ & $78(40.8)$ & \\
\hline Controlled use & $58(58.0)$ & $113(59.2)$ & \\
\hline
\end{tabular}

Note: $\uparrow$ Refers to year preceding treatment entry.

$* p<.05 ; \S p<.001$ 
Table 1 presents information on clients' backgrounds and substance abuse. The tables appear according to gender. Regarding the demographics, it can be stated in general that the clients' level of education was decidedly low and the level of unemployment correspondingly high. All in all the demographic information largely corresponded to the picture provided by earlier Finnish research regarding clients in substance abuse treatment in the community ${ }^{[64]}$.

Table 2. Therapists' $(N=30)$ background information

\begin{tabular}{|c|c|c|}
\hline Variables & $n$ & $\%$ \\
\hline Age (years) & 2 & 6.7 \\
\hline $31-40$ & 16 & 53.3 \\
\hline $41-50$ & 12 & 40.0 \\
\hline \multicolumn{3}{|l|}{$51-$} \\
\hline \multicolumn{3}{|l|}{ Marital status } \\
\hline Single & 62 & 24.2 \\
\hline Pair relationship & 193 & 75.7 \\
\hline \multicolumn{3}{|l|}{ Basic education } \\
\hline Comprehensive School & 8 & 26.7 \\
\hline Upper Secondary School & 22 & 73.3 \\
\hline \multicolumn{3}{|l|}{ Professional education } \\
\hline College or Polytechnic & 16 & 53.3 \\
\hline University & 14 & 46.7 \\
\hline \multicolumn{3}{|l|}{ Professional status / Job title } \\
\hline Registered nurse & 11 & 36.7 \\
\hline Social worker or therapist & 19 & 63.3 \\
\hline \multicolumn{3}{|c|}{$\begin{array}{l}\text { Length of experience in substance abuse } \\
\text { work }\end{array}$} \\
\hline Under 5 years & 8 & 26.7 \\
\hline $5-15$ years & 15 & 50.0 \\
\hline Over 15 years & 7 & 23.3 \\
\hline \multicolumn{3}{|l|}{ Therapeutic orientation } \\
\hline Cognitive therapies & 3 & 10.0 \\
\hline Motivational interview & 1 & 3.3 \\
\hline Solution-focused & 3 & 10.0 \\
\hline Psychodynamic & 1 & 3.3 \\
\hline Eclectic & 20 & 66.7 \\
\hline None of the foregoing & 2 & 6.7 \\
\hline \multicolumn{3}{|l|}{ Undergone long method training } \\
\hline Yes & 13 & 43.3 \\
\hline No & 17 & 56.7 \\
\hline
\end{tabular}

Alcohol was the primary substance abused, and there was a tendency towards the use of only one substance. As supplements to alcohol the most commonly used substances were tranquilisers, cannabis and amphetamine. The more recent arrival buprenorphine followed this group. It is illustrative of the substance abuse problems that the consumption of only one fifth of the clients was limited to weekends; albeit the share among those in inpatient treatment is even 
smaller ${ }^{[56]}$. It is also illustrative of the problematic consumption that almost half of the clients had had previous contacts with the clinic in question.

On the other hand the ability to control consumption emerged: approximately one fifth (18.9\%) of clients had been totally abstinent for the last month before commencing treatment. In prior international treatment research attention has likewise been paid to the fact that consumption is reduced prior to entering treatment ${ }^{[66,67]}$.

There was a statistically significant difference between male and female clients in three variables: marital status $\left(\chi^{2} 4=\right.$ $11.60 ; p=.02)$, experience of sexual violence or abuse $\left(\chi^{2} 1=66.1 ; p<.001\right)$ and in having previously been a client of the clinic in question $\left(\chi^{2} 1=5.33 ; p=.02\right)$. Men had a pair relationship more often than women, whereas women were more often divorced. Of the women almost 40 percent had been victims of sexual violence or exploitation while the corresponding figure for men was three percent. Men had more prior client relations than women to the clinic in question.

There was no difference between male and female clients as regards attending therapy; 85.1 percent of women and 86.7 percent of men attended. However, in participation in follow-up a gender difference emerged such that 56.4 percent of men attended follow-up but only 41.6 percent of women $\left(\chi^{2} 1=5.86 ; p=.02\right)$.

The average age of female clients was 43.8 years $(S D=10.6)$ and of male clients $42.2(S D=11.9)$. The therapists were on average some five years older than the clients $(M=48.5 ; S D=7.5)$. Table 2 presents demographic data on therapists including data on their therapeutic orientations.

Almost half of the therapists had professional higher education. Two thirds of them were social workers, while the rest were registered nurses. However, their job in all cases was therapy work with clients. Most of the therapists had worked in substance abuse treatment for a considerable time. The median of clients per worker was nine $(\min =1 ; \max =20)$. Among the individual therapy methods there emerged cognitive therapies, motivational interview and solution-focused therapies. Methodological eclecticism was, however, most common; almost two thirds of therapists used combinations of different methods.

\subsection{Data analyses}

The preliminary analyses are based on tests $\left(t\right.$ - and $\left.\chi^{2}\right)$ comparing differences in two independent samples. In the following analyses various regression models were used. SPSS for Windows 16.0 was used for the analyses.

\section{Results}

\subsection{Gender preferences}

First, male and female clients' preferences regarding their therapist's gender were compared. The preferences regarding therapist's gender differed statistically significantly between male and female clients $\left(\chi^{2} 2=14.68 ; p=.001\right)$. About half $(49.5 \%)$ of the women preferred to have a female therapist and only a small minority (3.0\%) preferred a male therapist. The other respondents did not feel that therapist's gender was important. However, male clients were less specific regarding the therapist's gender: just over a quarter of them (28.2\%) preferred a female therapist and only few (1.5\%) a male therapist. Approximately three quarters of the male clients $(70.3 \%)$ expressed no preference regarding therapist's gender.

\subsection{Gender differences in treatment effectiveness}

Gender differences in the therapeutic alliance were examined using $t$-tests. Variables measuring the quality of the therapeutic alliance assessed both by client and therapist at the first $\left(\operatorname{Ther} \mathrm{A}_{1} \mathrm{C}\right.$; $T$ her $\left.\mathrm{A}_{1} \mathrm{~T}\right)$ and third therapy sessions $\left(\mathrm{Ther}_{3} \mathrm{C}\right.$; Ther $\left.\mathrm{A}_{3} \mathrm{~T}\right)$ were included as well as the change in the therapeutic alliance between these therapy sessions among 
clients $\left(\right.$ Ther $\left.\mathrm{A}_{\mathrm{Ch}} \mathrm{C}\right)$ and among therapists $\left(\mathrm{Ther}_{\mathrm{Ch}} \mathrm{T}\right)$ (see Table 3). The estimates of the first and third sessions were merged into a composite score, the value of which described the change in the therapeutic alliance as treatment progressed. In evaluating the change, the variable could have either negative or positive value at individual level depending on the direction of the change. Therefore, the value describing change is a mean of individual remainders in the total sample.

Table 3. Therapeutic alliance, retention in treatment and treatment outcome by client's gender $\left(t-\right.$ and $\chi^{2}$-test)

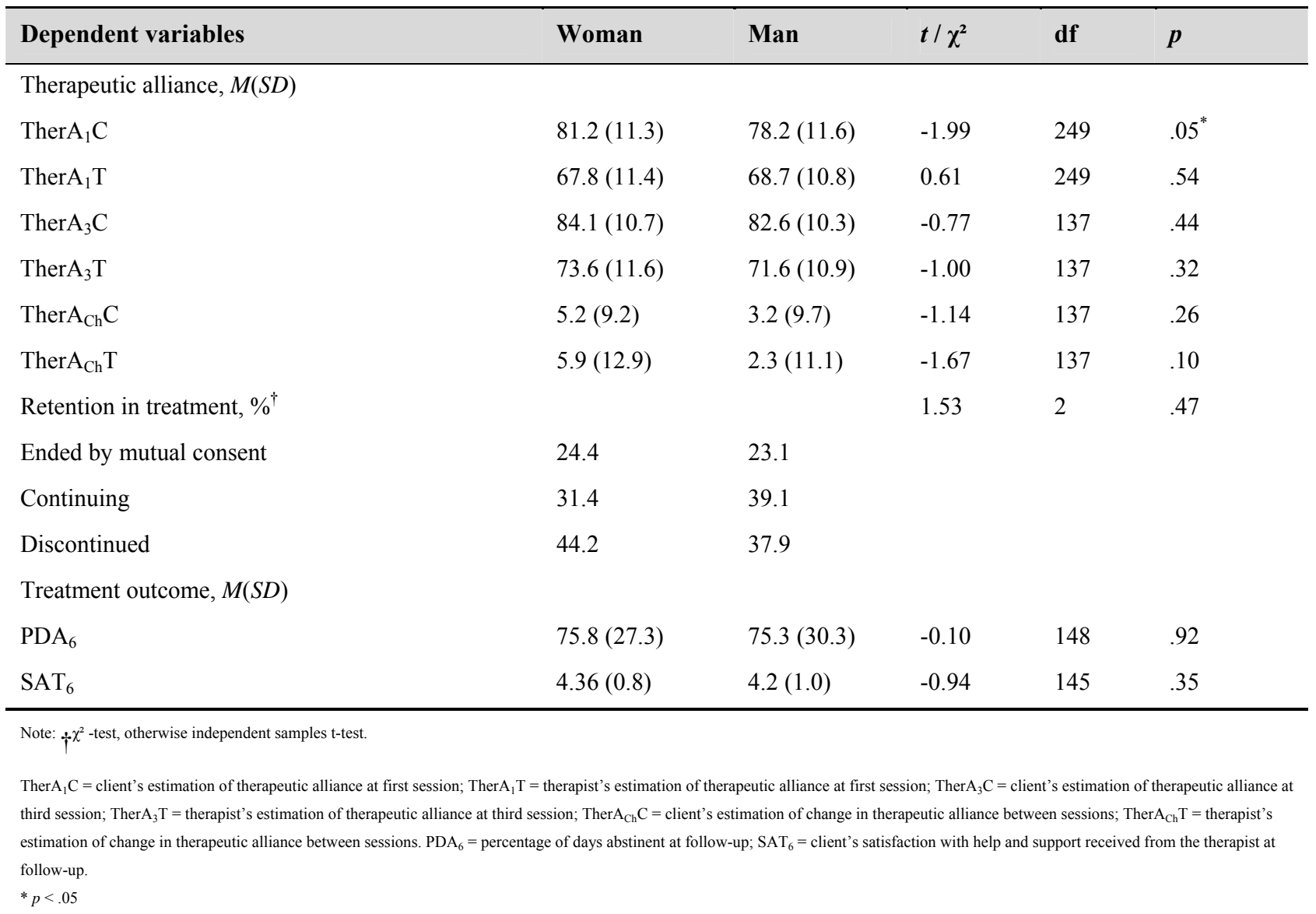

At each measurement point the clients estimated the therapeutic alliance on average some ten points higher than the therapists. The therapists' estimates of the therapeutic alliance with clients of different genders did not significantly differ from one another. On the other hand the views of female and male clients on the therapeutic alliance at the first treatment session differed significantly from each other, although the difference in favour of the estimates made by women was only some three points on a scale $0-100$.

On average, the change in the therapeutic alliance among female clients was slightly more positive than among male clients but the difference was not statistically significant. The estimates of the therapists also changed in the same direction; the therapeutic alliance with female clients strengthened a little more than it did with male clients as treatment progressed. However, the difference did not quite reach statistical significance.

\subsection{Gender-matching and treatment outcome}

Finally we checked whether there were differences in treatment outcomes between men and women (see Table 3). There was no difference between male and female clients as regards retention in treatment. The two other variables examined were: percentage of days abstinent during the month immediately preceding follow-up ( $\left.\mathrm{PDA}_{6}\right)$ and client's satisfaction with the help and support received from the therapist at follow-up $\left(\mathrm{SAT}_{6}\right)$. No significant differences emerged between 
male and female clients on these variables. It is nevertheless noteworthy that differences between genders did occur in participation in follow-up; the men were more active than the women in attending follow-up.

These results led us to conduct further analyses to explore the connection between gender and outcome measures used. According to our data on female therapists and their clients of both genders, it appeared in the preliminary analyses that gender match in a therapeutic relationship did not produce better results than gender mismatch. In the following analyses multivariate methods were used to study this phenomenon in more detail; outcome measures were used as dependent variables and four different regression analyses were conducted regarding therapeutic alliance, retention in treatment, percentage of days abstinent and satisfaction at follow-up with the treatment received. In all the models gender was considered as one of the independent variables; a dichotomous dummy variable was created by combining client and therapist gender into gender-match (female therapist-female client) and gender-mismatch (female therapist-male client). Other independent variables were added into the analyses on theoretical grounds and by taking the assumptions of the analyses into consideration.

To study the connection between gender and independent variables a slight modification of the response variables was made regarding measurement of the therapeutic alliance to better reveal its dyadic nature and change during treatment. A new dependent variable describing change in the direction of the alliance $\left(\mathrm{Ther}_{\mathrm{match}}\right)$ was created from two earlier variables describing change in the therapeutic alliance according to clients between the first and third therapy sessions $\left(\right.$ Ther $\left.\mathrm{A}_{\mathrm{Ch}} \mathrm{C}\right)$ and according to therapists $\left(\operatorname{Ther}_{\mathrm{Ch}} \mathrm{T}\right)$. When the alliance had evolved similarly between the client and the therapist it was considered a match in this variable (converging therapeutic alliance). Likewise, when the alliance assessed by the client diverged from the therapist's evaluation, it was regarded as alliance mismatch (diverging therapeutic alliance). This established variable was used as a dependent variable to study the effect of gender on the therapeutic alliance in a binary logistic regression model. The binary logistic regression model was used with the hierarchical method. The basic idea of hierarchical analysis is that independent variables are brought into the analysis in blocks; in this analysis they were divided into three blocks: 1) match-mismatch variables, 2) therapist-related variables and 3) client-related variables. The first block included gender match-mismatch, which is of special interest in all the remaining analyses. Gender seemed to predict the quality of the therapeutic alliance in this extensive exploratory analysis with two other independent variables. Therefore, the model was reduced and only these statistically significant variables were included in the final model: gender match-mismatch, voluntary admission attendance at the clinic and attitude towards medical treatment. This model explained $11.9-16.4 \%$ of the variance in the therapeutic alliance and was able to classify $69.1 \%$ of the cases $(5.1 \%$ more than constant). The overall percentage was weakened by the fact that the model was not able to predict diverging estimates of the quality of the therapeutic alliance very well $(26.0 \%)$. Nevertheless, in predicting converging estimates of the quality of the therapeutic alliance the model was more successful (93.3\%).

Table 4. Summary of binary logistic regression analysis for variables included in the model predicting therapeutic alliance

\begin{tabular}{llll}
\hline Variables & $\boldsymbol{\beta}$ & Expected $(\boldsymbol{B})$ & $\boldsymbol{p}$ \\
\hline Gender mismatch $^{\dagger}$ & -0.995 & 0.370 & $.02^{*}$ \\
Non-voluntary admission $^{\ddagger}$ & 1.071 & 2.919 & $.02^{*}$ \\
Attitude to medical treatment & 0.449 & 1.567 & $.00^{*}$ \\
\hline
\end{tabular}

Note: The reference categories in the categorical variables were: $\uparrow$ gender match; $\ddagger$ voluntary admission.

$* p<.05$

In the gender mismatch group the risk of belonging to the group of converging therapeutic alliance was 2.7 times smaller than in the gender match group; gender match predicted a better alliance (see Table 4). The non-voluntary attendance group was almost three times more successful in creating a converging alliance than the voluntary group. This could be explained by the necessity imposed from outside. In interpreting the quantitative variable, attitude towards medication, a 
logistic curve was created. When a client considered medication to be more important in recovery, the therapeutic alliance was more often convergent.

Gender had an effect only on the therapeutic alliance, not on other outcome variables (retention in treatment; percentage of days abstinent at follow-up, $\mathrm{PDA}_{6}$; satisfaction with the treatment received at follow-up, $\mathrm{SAT}_{6}$ ). Multinomial regression analysis was used to study predictors of retention in treatment (see Table 5). The reference category selected was "treatment period discontinued" (40.0\%), with which the categories "treatment was ended by mutual consent" $(23.5 \%)$ and "treatment period ongoing" (36.5\%) were compared. The independent variables were again match-mismatch variables, therapist-related variables and client-related variables. The findings showed that gender match-mismatch was not able to predict retention in treatment.

Table 5. Summary of multinomial logistic regression analysis for variables predicting retention in treatment

\begin{tabular}{|c|c|c|c|}
\hline Variables & $\boldsymbol{\beta}$ & Expected $(B)$ & $p$ \\
\hline \multicolumn{4}{|l|}{ Ended by mutual consent $^{\dagger}$} \\
\hline Self-efficacy & 0.468 & 1.597 & $.03^{*}$ \\
\hline Readiness to change & -0.131 & 0.877 & .09 \\
\hline Therapist's basic education ${ }^{a}$ & 1.316 & 3.728 & $.01^{\S}$ \\
\hline Therapist's professional education ${ }^{\mathrm{b}}$ & -1.844 & 0.158 & $.01^{\S}$ \\
\hline \multicolumn{4}{|l|}{ Treatment continues $^{\dagger}$} \\
\hline Self-efficacy & 0.426 & 1.532 & $.02^{*}$ \\
\hline Therapist's professional status ${ }^{\mathrm{c}}$ & 1.131 & 3.098 & $.05^{*}$ \\
\hline
\end{tabular}

Three of the independent variables were statistically significant in the model: client's self-efficacy $\chi^{2} 2=6.96, p=.03$; therapist's basic education $\chi^{22}=15.83, p=.000$; therapists' professional education $\chi^{22}=7.26, p=.03$. Gender match-mismatch was not among them. Those whose therapy was discontinued differed statistically significantly from the other two groups. When comparing those who had ended their therapy in agreement with those that had dropped out, the odds of belonging in the former group increased with the increase in self-efficacy. When therapist's basic education was comprehensive school (basic education to age 16) risk of ending therapy by mutual consent was almost four times higher than of those therapists who had upper secondary school (secondary education to age 18 or so) background. Further, those working as a registered nurses were at smaller risk (over 6-times) of discontinuing therapy by mutual agreement when compared to university level therapists, when the reference category was therapy discontinued. When comparing those clients who had continued the treatment with the drop-outs, the odds of being among those whose treatment had continued increased with the increase in client's self-efficacy. The likelihood of therapists with professional background as nurses continuing therapy compared to that of ending therapy was over three times higher than that of employees working as social workers or therapists. This result could be explained by a tendency towards medication in substance abuse treatment.

Finally, quantitative dependent variables $\left(\mathrm{PDA}_{6} ; \mathrm{SAT}_{6}\right)$ were examined with multiple regression analysis using the hierarchical method (see Table 6). Independent match-mismatch variables, therapist-related variables and client-related variables were brought into the analysis in blocks.

When $\mathrm{PDA}_{6}$ was a response variable, it turned out that only client-related variables were statistically significant $(\mathrm{F}=1.63$; $p=.03$ ). The match-mismatch block was able to predict only $0.4 \%$ of the variance and after second block therapist 
variables together with match-mismatch variables predicted $13.1 \%$ of the variance. When client variables were included in the model it predicted $37.5 \%$ of the variance in treatment outcome measured by percentage of days abstinent at follow-up. In the first block age difference between client and therapist was a statistically significant predictor of better treatment results; when age difference rose treatment results were better. It remained statistically significant when the second block was added to the analysis. No other variables were statistically significant until in the third model, where therapist's experience of sexual abuse became significant with client's substance use at baseline; therapist's experience of sexual abuse made the client's treatment results slightly better. Also, more days abstinent at baseline predicted better results at follow-up. There was also a trend regarding future substance use; when the client aimed at abstinence instead of moderate use results improved.

Table 6. Summary of linear regression analysis for variables predicting percentage of days abstinent and satisfaction with the therapist at follow-up

\begin{tabular}{|c|c|c|c|}
\hline Variables & $t$ & $\beta$ & $p$ \\
\hline \multicolumn{4}{|l|}{$\mathrm{PDA}_{6}^{\dagger}$} \\
\hline \multicolumn{4}{|l|}{ Block $1\left(\mathrm{R}^{2}=0.4 \%\right)$} \\
\hline Client-therapist age difference & 1.986 & 0.175 & $.05^{*}$ \\
\hline \multicolumn{4}{|l|}{ Block $2\left(\mathrm{R}^{2}=9.7 \%\right)$} \\
\hline Client-therapist age difference & 2.204 & 0.206 & $.03^{*}$ \\
\hline \multicolumn{4}{|l|}{ Block $3\left(\mathrm{R}^{2}=24.4 \%\right)^{*}$} \\
\hline Therapist's experience of sexual abuse & 2.082 & 0.309 & $.04^{*}$ \\
\hline Client's substance use at baseline & 2.611 & 0.279 & $.01^{\S}$ \\
\hline Objective for future substance use & 1.779 & 0.189 & .08 \\
\hline \multicolumn{4}{|l|}{$\mathrm{SAT}_{6}^{\ddagger}$} \\
\hline \multicolumn{4}{|l|}{ Block $1\left(\mathrm{R}^{2}=1.0 \%\right)$} \\
\hline \multicolumn{4}{|l|}{ No significant predictors } \\
\hline \multicolumn{4}{|l|}{ Block $2\left(\mathrm{R}^{2}=15.9 \%\right)$} \\
\hline Therapist's genuineness & -1.935 & -0.849 & .06 \\
\hline \multicolumn{4}{|l|}{ Block $3\left(\mathrm{R}^{2}=20.6 \%\right)^{*}$} \\
\hline Client's religiousness & 2.099 & 0.223 & $.04^{*}$ \\
\hline Client's outcome expectations & 2.408 & 0.235 & $.02^{*}$ \\
\hline
\end{tabular}

Note: PDA indicates percentage of days abstinent at 6 months follow-up. $\mathrm{SAT}_{6}$ indicates satisfaction with the therapist at 6 months follow-up.

$\dagger R^{2}=0.38$, Adjusted $R^{2}=0.15$.

$\$ \mathrm{R}^{2}=0.37$, Adjusted $\mathrm{R}^{2}=0.14$.

${ }^{*} p<.05 ; \S p<.01$.

Again, with $\mathrm{SAT}_{6}$ as a dependent variable only client variables were statistically significant $(\mathrm{F}=1.61 ; p=.04)$. The match-mismatch block was now able to predict only $1.0 \%$ of the variance and together with therapist variables $16.9 \%$. Client variables were able to predict most of the variance, thus the whole model predicted $37.4 \%$ of the variance of the satisfaction with the treatment received. No variables in the first block were statistically significant. In the second block therapist's genuineness could be seen as a trend by being near to statistical significance. This was a confusing result; the more genuine the therapist was evaluated by independent evaluators ${ }^{[69]}$ the less satisfied the client was. The third block eliminated the statistical significance of therapist's genuineness and instead client's own religiosity and client's outcome 
expectations became significant predictors; religious clients and those with better outcome expectations were more satisfied with their therapists.

\section{Discussion}

On certain background variables male and female clients differed statistically significantly from each other. More women than men were divorced. They had also experienced considerably more sexual violence or abuse. More men for their part had already been clients of the treatment facility in question. Moreover, men participated more actively than women in follow-up.

There were differences between men and women in their preferences regarding therapist's gender: half of the women preferred a female therapist while only a quarter of the men did so. A small minority of clients expressly requested a male therapist: they amounted to only two percent of all clients the entire data. The others did not consider the therapist's gender important. The fact that women expressed more preferences regarding therapist's gender may to some extent be explained by the fact that several of them had been subjected to sexual violence or exploitation. On the other hand female clients may have preferred a therapist of the same gender either because of shared gender experience or because a female therapist was felt to be more empathetic than a male therapist.

But what explains the fact that male clients, when expressing a preference, request a female therapist? Is it the empathetic nature, non-directiveness ${ }^{[51]}$ or something else? This remains open to speculation. The realization of gender-sensitive treatment practices regarding gender matching is rarely possible for men because of the small number of male therapists available. It may be that male clients do not make such demands and this is due to their expectations regarding the therapist's gender. It should be remembered that males had more often had prior treatment experience and female dominance of the professional treatment field is a fact for most of them on entering treatment. While more experienced as clients, their past experiences with female therapists may also affect whether they prefer a therapist of a certain gender.

The ways female and male clients felt about the therapeutic alliance differed at the first therapy session such that women estimated the therapeutic alliance to be somewhat better. It is open to speculation to what extent this is attributable to common gender and the basis this created for co-operation. It may also be that women are disposed to estimate the therapeutic alliance more positively than are men. However, as treatment continued the difference in clients' estimates between genders was no longer perceptible. The therapists' estimations of the alliance did not differ by client's gender. Nor were there gender differences in retention or treatment outcome. Also, gender match produced no better treatment results than did gender mismatch in most multivariate analyses used except regarding the therapeutic alliance. The therapeutic alliance could be considered to be not a direct outcome measure, but more like a variable that could have an eventual effect on treatment outcome. It has been concluded that a better alliance can lead to better treatment results ${ }^{[27]}$. This could not be shown in our analyses; the effect of gender matching and its influence on a better therapeutic alliance was restricted regarding outcome.

\section{Limitations}

The principles which can be deemed the strength of this study appear in the methods section. However, the study has some limitations, which should be born in mind when considering the results. The most important of these is probably that the follow-up was only for six months and a maximum of five sessions per client. The length of follow-up could be justified by the dynamics of substance abuse treatment: relapses most commonly peak during that time. However, further information on the clients' subsequent trajectories would have been useful but this was not possible due to the schedule of the research project.

The sample for the study was regionally representative of clients entering treatment facilities for outpatient substance abuse treatment. According to an earlier study, however, it differs from clients in residential treatment; among clients 
treated in the community the substance abuse problems are generally not as severe as among residential clients ${ }^{[68]}$. This impairs the generalizability of the study at hand.

The sample size also affects whether it is possible to detect a difference in therapeutic alliance between genders. In the analyses used the sample size should be enough to avoid type II errors. The sample size was adequate according to the preliminary sample size calculations. Also, the naturalistic approach of this study has an effect on the sample size reached.

The dropout rate should also be taken into account when interpreting the findings. Follow-up reached 51.3 percent of those entering the study, and more female clients in particular were lost to follow-up than males. This high dropout rate is in part explained by the naturalistic unselected sample. This may also have an effect on selection; some people may have a greater chance of dropping out of treatment. However, the selection problem has been noted in the attrition analyses in our earlier studies ${ }^{[54,69]}$. It was concluded that positive outcome expectations improved the probability of entering therapy. Overall, it seemed that the stability of life built up with increasing age and less problematic substance use supported retention in treatment after the treatment had begun. Systematic controlling of mediating variables available in multivariate analyses works in the same direction. No information on the number of clients or reasons for not attending the study was gathered because of the Finnish legislation prohibiting double registration while doing research.

\section{Conclusions}

To the best of our knowledge no outcome research on this particular aspect has so far been reported as regards substance abuse treatment. The fact that no major differences by gender were found in therapist's estimation of the alliance or treatment outcome suggests that female therapists provide quite uniform treatment whether the client is male or female, at least according to the measures used, although a positive effect of gender matching regarding therapeutic alliance was found. Thus there would not appear to be a case for practices in Finnish outpatient substance abuse treatment taking greater account of client's gender - at least not as regards female therapists and their clients. The results obtained, however, do not exclude the possibility that matching client and therapist for gender might yield even better treatment results, in fact it does this regarding the therapeutic alliance. Female clients frequently preferred a female therapist, and meeting these expectations may be beneficial to retention in treatment and eventually treatment outcome. It may also have been that without gender matching follow-up attendance or other treatment outcome measures would have been even worse in women; males fared better measured by attendance at follow-up.

The findings do not permit us to conclude why women were so few in follow-up. We can only conjecture. Perhaps continuing in treatment is governed more by social pressure or lack thereof than by gendered treatment received by clients. A man in a pair relationship probably receives more encouragement to enter treatment than does a woman, as a woman with a substance abuse problem is more likely to be divorced. Thus women who drink receive less support from their immediate environment to sober up and possibly experience less social pressure to change their ways than do men who $\operatorname{drink}^{[36]}$.

Substance abuse treatment concerns men more frequently than women as clients. Yet the therapist is more often a woman than a man. The most typical client relationship in substance abuse is the woman as therapist and the man as client. On the one hand the fact that the therapists are typically women and women as clients are less typical may constitute a risk to a functioning therapeutic alliance and successful outcome. Thus it is imperative that personnel's attitudes should not permit gender to emerge as a factor inhibiting the provision of care even though it may require differences in actual treatment practices and this possibly affects the provision of equally good care.

In light of this study we conclude that in the therapy situation in outpatient substance abuse treatment client's gender does not emerge as an inhibitory or deleterious factor, at least as far as treatment outcome is concerned. Substance abuse treatment is likely a field less affected by gender than, for example, child protection, in which there are many more 
tensions surrounding a man's position ${ }^{[70]}$. And although alcohol and aggression are often seen to go hand in hand, contrary to the interpretation of Leo Nyqvist ${ }^{[37]}$, the fears of female therapists in substance abuse treatment do not appear to have a deleterious effect on the therapeutic alliance with regard to men.

Research on the significance of gender in the therapeutic alliance in substance abuse treatment is in its infancy, also internationally. This study showed that female therapists' clients' gender did not lead to major differences in treatment outcome in outpatient substance abuse treatment. The treatment and support received by clients of different genders may differ in certain respects and be purposefully gendered. Moreover, clients who have experienced sexual exploitation may feel that the gender of the therapist is of particular importance. Adamson et al. ${ }^{[71]}$ discovered that despite high rates of sexual abuse among the substance abusing population and its significance in predicting onset of substance use disorder, it has been rarely in focus of outcome studies in substance abuse treatment field. A more precise analysis of the treatment process would entail the use of qualitative methods in treatment outcome research, maybe together with quantitative methods. In all, the phenomenon of sexual abuse and its connection with substance abuse treatment needs more attention.

Nationally, the small number of male therapists in facilities for the treatment of substance abuse in the community constitutes a problem for research of this type; comparison between male and female therapists is in practice extremely problematic. Whether these finding also apply to male workers and their clients is so far unresolved. Today, men provide care in substantial numbers also professionally. The inclusion of male workers would likewise be important, although in practice this is not easy in a Finnish treatment context, especially in outpatient settings; a larger sample of treatment units and their male therapists would be needed.

\section{Acknowledgment}

Funding for this study was provided by the Academy of Finland, Research Programme on Substance Use and Addictions 2007-2010 to the Research Group headed by Professor Pekka Saarnio on Effectiveness of Substance Abuse Treatment in Light of Common Factors, University of Tampere, Finland (grant 118327).

\section{Authors' contributions}

KK was Principal Investigator and responsible for the conceptualization, conduct and management of this study and analysis plan, analysis, interpretation of results and drafting of the manuscript and finalizing it.

TA contributed to the conceptualization of the manuscript and drafting of the manuscript regarding introduction-section. Both authors have read and approved the final manuscript.

\section{Disclosure of conflicts of interest}

The authors declare that they have no conflicts of interest.

\section{References}

[1] Gillingham P. Male social workers in child and family welfare: New directions for Research. Soc Work. 2006 Jan; 51(1): 83-5. PMid:16512514 http://dx.doi.org/10.1093/sw/51.1.83

[2] Straussner SLA, Zelvin E. Gender and addictions. Men and women in treatment. Lanham: Rowman \& Littlefield Publishers; 2006.

[3] Straussner SLA, Brown S. The handbook of addiction treatment for women. Theory and practice. San Francisco: Jossey-Bass; 2002. PMid:23581004

[4] Brady KT, Back SE, Greenfield SF. Women \& addiction. A comprehensive handbook. New York: The Guilford Press; 2009.

[5] Greenfield SF, Brooks AJ, Gordon SM, Green CA, Kropp F, McHugh RK, Lincoln M, Hien M, Miele GM. Substance abuse treatment entry, retention, and outcome in women: A review of the literature. Drug Alcohol Depen. 2007 Jan; 86(1):1-21. PMid:16759822 http://dx.doi.org/10.1016/j.drugalcdep.2006.05.012

[6] Storbjörk J. Gender differences in substance use, problems, social situation and treatment experiences among clients entering addiction treatment in Stockholm. Nord Stud Alcohol Drugs. 2011 Aug; 28(3):185-209. 
[7] Straussner SLA. Gender and substance use. In: Straussner SLA, Zelvin E, eds. Gender and addictions. Men and women in treatment. Lanham: Rowman \& Littlefield Publishers; 2006.

[8] Ahlström S. Vertaileva tutkimusprojekti sukupuolten suhteista ja alkoholista. Yhteiskuntapolitiikka 2000 65(5):447-9.

[9] Holmila M. Perhe, päihteet ja sukupuoli. Yhteiskuntapolitiikka. 2001; 66(1):55-62.

[10] Nuorvala Y, Huhtanen P, Ahtola R, Metso L. Huono-osaisuus mutkistuu. Kuudes päihdetapauslaskenta 2007. Yhteiskuntapolitiikka. 2008; 73(6):659-70.

[11] Greenfield SF, Pirard S. Gender-specific treatment for women with substance use disorders. In: Brady KT, Back SE, Greenfield SF, eds. Women and addiction. A comprehensive handbook. New York: The Guilford Press; 2009.

[12] Forsberg H, Kuronen M, Ritala-Koskinen A. Feministinen sosiaalityö - kysymyksiä ja uusia kysymyksiä. Janus. 1992; 1:3-9.

[13] Kuronen M. Valtaistumista vai voimavaraistumista - Feministisiä näkökulmia empowermentiin sosiaalityön käsitteenä ja käytäntönä. In: Kuronen M, Granfelt R, Nyqvist L, Petrelius P, eds. Sukupuoli ja sosiaalityö. Jyväskylä: PS-kustannus; 2004.

[14] Randall CL, Del Boca FK, Mattson ME, Rychtarik R, Cooney NL, Donovan DM, Longabaugh R, Wirtz PW. Primary treatment outcomes and matching effects: Aftercare arm. In: Babor, TF, Del Boca FK, eds. Treatment Matching in Alcoholism. New York: Cambridge University Press; 2003.

[15] Imel ZE, Wampold BE, Miller SD, Fleming RR. Distinctions without a difference: direct comparisons of psychotherapies for alcohol use disorders. Psychol Addict Behav. 2008 Dec; 22(4):533-43. PMid:19071978 http://dx.doi.org/10.1037/a0013171

[16] UKATT Research Team. Effectiveness of treatment for alcohol problems: findings of the Randomized UK alcohol treatment trial (UKATT). Brit Med J. 2005a; 331(7516):541-4. PMid:16150764 http://dx.doi.org/10.1136/bmj.331.7516.541

[17] UKATT Research Team. Cost effectiveness of treatment for alcohol problems: findings of the randomized UK alcohol treatment trial (UKATT). Brit Med J. 2005b; 331(7516): 544-8. PMid:16150765 http://dx.doi.org/10.1136/bmj.331.7516.544

[18] McLellan AT, Grissom GR, Zanis D, Randall M, Brill P, O’Brien C. Problem-service "matching" in addiction treatment: A prospective study in four programs. Arch Gen Psychiat. 1997 Aug; 54(8):730-5. PMid:9283508 http://dx.doi.org/10.1001/archpsyc.1997.01830200062008

[19] Blow AJ, Timm TM, Cox R. The role of the therapist in therapeutic change: Does therapist gender matter? Journal of Feminist Family Therapy. 2008 Sep; 20(1):66-86. http://dx.doi.org/10.1080/0895280801907150

[20] Beutler L, Malik M, Alimohamed S, Harwood TM, Talebi H, Noble S, Wong E. Therapist variables. In: Lambert M, ed. Handbook of psychotherapy and behavior change. New York: Wiley; 2004.

[21] Martin DJ, Garske JP, Davis MK. Relation of the therapeutic alliance with outcome and other variables: A meta-analytic review. J Consul Clin Psych. 2000 Jun; 68(3):438-50. PMid:10883561 http://dx.doi.org/10.1037/0022-006X.68.3.438

[22] Messer SB, Wampold BE. Let's face facts: Common factors are more potent than specific therapy ingredients. Clin Psychol-Sci Pr. 2002 Mar; 9(1):21-5. http://dx.doi.org/10.1093/clipsy.9.1.21

[23] Najavits LM, Crits-Christoph P, Dierberger A. Clinicians impact on the quality of substance use disorder treatment. Subst Use Misuse. 2000; 35(12-14):2161-90. PMid:11138720 http://dx.doi.org/10.3109/10826080009148253

[24] Schneider U, Kroemer-Olbrisch T, Wedegartner F, Cimander KF, Wetterling T. Wishes and expectations of alcoholic patients concerning their therapy. Alcohol Alcoholism. 2004 Mar; 39(2):141-5. PMid:14998832 http://dx.doi.org/10.1093/alcalc/agh029

[25] Beutler LE. The dodo bird is extinct. Clin Psychol-Sci Pr. 2002 Mar; 9(1):30-4. http://dx.doi.org/10.1093/clipsy.9.1.30

[26] Rychtarik RG, Connors GJ, Whitney R, McGillicuddy N, Fitterling J. Treatment settings for persons with alcoholism: Evidence for matching clients to inpatient versus outpatient care. J Consult Clin Psych. 2000 Apr; 68(2):277-89. PMid:10780128 http://dx.doi.org/10.1037/0022-006X.68.2.277

[27] Horvath AO, Bedi RP. The Alliance. In: Norcross JC, ed. Psychotherapy relationships that work: Therapist contributions and responsiveness to patients. Oxford: Oxford University Press; 2002.

[28] Hatcher RL, Barends AW. How a return to theory could help alliance research. Psychother. 2006 Fall; 43(3):292-9. PMid:22122100 http://dx.doi.org/10.1037/0033-3204.43.3.292

[29] Marcus DK, Kashy DA, Baldwin SA. Studying psychotherapy using the one-with-many design: The therapeutic alliance as an exemplar. J Consul Clin Psych. 2009 Oct; 56(4):537-48.

[30] Grella CE, Scott CK, Foss MA, Dennis ML. Gender similarities and differences in the treatment, relapse and recovery cycle. Eval Rev. 2008 Feb; 32(1):113-37. PMid:18198172 http://dx.doi.org/10.1177/0193841X07307318

[31] Fowler WE, Wagner WG. Preferences for comfort with male versus female counselors among sexually abused girls in individual treatment. J Couns Psychol; 1993 Jan; 40(1):65-72. http://dx.doi.org/10.1037/0022-0167.40.1.65

[32] Claus RE, Orwin RG, Kissin W, Krupski A, Campbell K, Stark K. Does gender-specific substance abuse treatment for women promote continuity of care? J Subst Abuse Treat. 2007 Jan; 32(1):27-39. PMid:17175396 http://dx.doi.org/10.1016/j.jsat.2006.06.013 
[33] Sterling RC, Gottheil E, Weinstein SP, Serota R. The effect of therapist/patient race- and sex-matching in individual treatment. Addiction. 2001 Jul; 96(7):1015-22. PMid:11440612 http://dx.doi.org/10.1046/j.1360-0443.2001.967101511.x

[34] Fiorentine R, Hillhouse MP. Drug treatment effectiveness and client-counselor empathy: Exploring the effects of gender and ethnic congruency. J Drug Issues. 1999 Jan; 29(1):59-74.

[35] Wintersteen MB, Mensinger JL, Diamond GS. Do gender and racial differences between patient and therapist affect therapeutic alliance and treatment retention in adolescence. Prof Psychol-Res Pr. 2005 Aug; 36(4):400-8. http://dx.doi.org/10.1037/0735-7028.36.4.400

[36] Grella CE. Treatment seeking and utilization among women with substance use disorders. In: Brady KT, Back SE, Greenfield SF, eds. Women and addiction. A comprehensive handbook. New York: The Guilford Press; 2009.

[37] Nyqvist L. Sukupuoli parisuhdeväkivallan ammatillisessa kohtaamisessa. In: Kuronen M, Granfelt R, Nyqvist L, Petrelius P, eds. Sukupuoli ja sosiaalityö. Jyväskylä: PS-kustannus; 2004.

[38] Seligson A. Sosiaaliala ja sukupuoli. Sosiaalialan kehittämishankkeen sukupuolinäkökulman valtavirtaistaminen. Sosiaali- ja terveysministeriön selvityksiä. 2007:70. Helsinki: Sosiaali- ja terveysministeriö; 2008.

[39] Cayouette S. Safety issues for women co-facilitating groups for violent men. In: Wild J, ed. Working with men for change. Lontoo: Routledge; 1999. PMid:10600408

[40] Tudor K. Men in therapy: opportunity and change. In: Wild J, ed. Working with men for change. London: Routledge; 1999.

[41] Ritter A, Bowden S, Murray T, Ross P, Greeley J, Pead J. The influence of the therapeutic relationship in treatment for alcohol dependency. Drug Alcohol Rev. 2002; 21(3): 261-8. PMid:12270077 http://dx.doi.org/10.1080/0959523021000002723

[42] Karno MP, Longabaugh R. Less directiveness by therapists improves drinking outcomes of reactant clients in alcoholism treatment. J Consult Clin Psych. 2005 Apr; 73(2):262-7. PMid:15796633 http://dx.doi.org/10.1037/0022-006X.73.2.262

[43] Macdonald J, Cartwright A, Brown G. A quantitative and qualitative exploration of client-therapist interaction and engagement in treatment in an alcohol service. Psychol Psychother-t. 2007 Jun; 80(2):247-68. PMid:17535598 http://dx.doi.org/10.1348/147608306X156553

[44] DeJong CA, van den Brink W, Jansen JAM. Sex role stereotypes and clinical judgement: How therapists view their alcoholic patients. J Subst Abuse Treat. 1993 Jul-Aug; 10(4):383-9. http://dx.doi.org/10.1016/0740-5472(93)90023-U

[45] Cooney NL, Babor TF, DiClemente CC, Del Boca FK . Clinical and scientific implications of Project MATCH. In: Babor, TF, Del Boca FK, eds. Treatment Matching in Alcoholism. New York: Cambridge University Press; 2003.

[46] Kauffman E, Dore MM, Nelson-Zlupko L. The role of women's therapy groups in the treatment of chemical dependence. Am J Orthopsychiat. 1995 Jul; 65(3):355-63. PMid:7485421 http://dx.doi.org/10.1037/h0079657

[47] Copeland J. A qualitative study of barriers to formal treatment among women who self-managed change in addictive behaviours. J Subst Abuse Treat. 1997 Mar-Apr; 14(2):183-90. http://dx.doi.org/10.1016/S0740-5472(96)00108-0

[48] Saarnio P, Tolonen M, Heikkilä K, Kangassalo S, Niitty-Uotila P, Vilenius L, Virtanen K, Mäkeläinen M-L. Päihdeongelmaisten selviytyminen hoidon jälkeen. Sosiaalilääketieteellinen Aikakauslehti. 1998; 35(4):207-19.

[49] Hänninen J. Sosiaalityön miehet ja huoltapitävä valta. In: Kuronen M, Granfelt R, Nyqvist L, Petrelius P, eds. Sukupuoli ja sosiaalityö. Jyväskylä: PS-kustannus; 2004.

[50] Miller WR, Rose GS. Toward a theory of motivational interviewing. Am Psychol. 2009 Sept; 64(6):527-37. PMid:19739882 http://dx.doi.org/10.1037/a0016830

[51] Saarnio P. Big five personality traits and interpersonal functioning in female and male substance abuse therapists. Subst Use Misuse. 2010 Aug; 45(10):1463-73. PMid:20438330 http://dx.doi.org/10.3109/10826081003749963

[52] Kuusisto K, Artkoski T, Saarnio P. Päihdehoidon naistyöntekijä ja asiakkaan sukupuoli [Female therapist and the gender of the client in substance abuse treatment]. Naistutkimus. 2011; 24(1):30-42. Finnish.

[53] Knuuttila V, Kuusisto K, Saarnio P, Nummi T. Early working alliance in outpatient substance abuse treatment: Predicting substance use frequency and client satisfaction. Clinical Psychologist. 2012 Nov; 16(3):123-35. http://dx.doi.org/10.1111/j.1742-9552.2012.00049.x

[54] Knuuttila V, Kuusisto K, Saarnio P. Client characteristics and therapist style: A combined analysis of impact on retention and effectiveness in outpatient substance abuse treatment. Nord Stud Alcohol Drugs. 2011 Nov; 28(4):321-38.

[55] Saarnio P, Knuuttila V. A study of risk factors in dropping out from inpatient treatment of substance abuse. J Subst Use. 2003 Apr; 8(1):33-8. http://dx.doi.org/10.1080/1465989031000067227

[56] Saarnio P, Knuuttila V. A study of readiness to change profiles in alcohol and other drug abusers. J Addict Nurs. 2007; 18(3):117-22. http://dx.doi.org/10.1080/10884600701500602

[57] Bethea AR, Acosta MC, Haller DL. Patient versus therapist alliance: Whose perception matters? J Subst Abuse Treat. 2008 Sept; 35(2):174-83. PMid:18082997 http://dx.doi.org/10.1016/j.jsat.2007.09.007 
[58] Horvath AO. The alliance in context: Accomplishments, challenges, and future directions. Psychother Theor Res Pract Train. 2006 Fall; 43(3):258-63. PMid:22122094 http://dx.doi.org/10.1037/0033-3204.43.3.258

[59] Simpson DD, Joe GW, Rowan-Szal GA, Greener JM. Drug abuse treatment process components that improve retention. J Subst Abuse Treat. 1997 Nov-Dec; 14(6):565-72. http://dx.doi.org/10.1016/S0740-5472(97)00181-5

[60] Brochu S, Cournoyer L, Tremblay J, Bergeron J, Brunelle N, Landry M. Understanding treatment impact on drug-addicted offenders. Subst Use Misuse. 2006 Jan; 41(14):1937-49. PMid:17162598 http://dx.doi.org/10.1080/10826080601025995

[61] Connors GJ, Carroll KM, DiClemente CC, Longabaugh R, Donovan DM. The therapeutic alliance and its relationship to alcoholism treatment participation and outcome. J Consult Clin Psych. 1997 Aug; 65(4):588-98. PMid:9256560 http://dx.doi.org/10.1037/0022-006X.65.4.588

[62] Fenton LR, Cecero JJ, Nich C, Frankforter TL, Carroll KM. Perspective is everything: The predictive validity of six working alliance instruments. J Psychother Pract Res. 2001 Fall; 10(4):262-8. PMid:11696653

[63] Ojanen M. Liikunta ja psyykkinen hyvinvointi. Helsinki: Liikuntatieteellinen seura;1994.

[64] Saarnio P. Factors associated with dropping out from outpatient treatment of alcohol-other drug abuse. Alcsm Treat Quart; 2002 20(2):17-33.

[65] Kirschenbaum AP, Olsen DM, Bickel WK. A quantitative review of the ubiquitous relapse curve. J Subst Abuse Treat. 2009 Jan; 36(1):8-17. PMid:18571890 http://dx.doi.org/10.1016/j.jsat.2008.04.001

[66] Stout R, Del Boca FK, Carbonari J, Rychtarik R, Litt MD, Cooney N. Primary treatment outcomes and matching effects: Outpatient arm. In: Babor, TF, Del Boca FK, eds. Treatment Matching in Alcoholism. New York: Cambridge University Press; 2003.

[67] Bergmark A. Specific and contextual treatment mechanisms. Nord Stud Alcohol Drugs. 2008; 25(4):285-93.

[68] Saarnio P, Knuuttila V. Readiness to change profiles in two different groups of Alcohol/Other drug abusers in the United States and Finland. Alcsm Treat Quart. 2008; 26(3):333-46. http://dx.doi.org/10.1080/07347320802072099

[69] Kuusisto K, Knuuttila V, Saarnio P. Pre-treatment expectations in clients: Impact on retention and effectiveness in outpatient substance abuse treatment. Behav Cogn Psychoth. 2011 May; 39(3):257-71. PMid:21489349 http://dx.doi.org/10.1017/S1352465810000846

[70] Scourfield JB. Constructing men in child protection work. Men Masc. 2001 Jul; 4(1):70-89. http://dx.doi.org/10.1177/1097184X01004001004

[71] Adamson SJ, Sellman JD, Frampton CMA. Patient predictors of alcohol treatment outcome: A systematic review. J Subst Abuse Treat. 2009 Jan; 36(1):75-86. PMid:18657940 http://dx.doi.org/10.1016/j.jsat.2008.05.007 